\title{
ИСПОЛЬЗОВАНИЕ ПСИХОБИОТИКОВ ДЛЯ ДИМИНУАЦИИ СТРЕССОГЕННЫХ ПОСЛЕДСТВИЙ COVID-19
}

\author{
Леорда Анна Ивановна \\ Кандидат биологических наук, ведущий научный сотрудник, \\ Институт физиологии и санокреатологи, г. Китинев \\ Гараева Светлана Николаевна \\ Кандидат биологических наук, ведущий научный сотрудник, \\ Институт физиологии и санокреатологии, г. Кишинев \\ Толстенко Дорина Александровна \\ Врач-лаборант, \\ ГУ Центр матери и ребенка, г. Кишинев
}

\begin{abstract}
Аннотация. Двусторонняя связь между кишечником и мозгом становится уязвимой в стрессогенных условиях пандемии, при которых страдает нормальная микрофлора ЖКТ психобиотического действия, что приводит к снижению стрессоустойчивости и к депрессии. Введение препаратов, содержащих штаммы психобиотиков, а также некоторых аминокислот позволит положительно влиять как на регуляцию психических функций, так и на бактериоценоз кишечника в условиях пандемии и/или постпандемии COVID-19. Уровень триптофана в плазме крови может служить биомаркером в процессе выбора оптимальной терапии психических нарушений в условиях пандемии.

Summary. The gut-brain interconnection becomes vulnerable in the pandemic stressful conditions, in which the normal psychobiotic action micro flora of the gastrointestinal tract suffers, which leads to a decrease in stress resistance and depression. The inclusion of microbial associations containing strains of psychobiotics, as well as some amino acids, in the diet will positively influence both the regulation of mental functions and intestinal bacteriocenosis in the context of a COVID-19 pandemic and / or post-pandemic. The level of tryptophan in blood plasma can serve asa biomarker in the process of choosing the optimal therapy for mental disorders in a pandemic conditions.

Ключевые слова: психобиотики, COVID-19, желудочно-кишечные симптомы, микробиота кишечника, дисбактериоз, депрессия, ГАМК, триптофан.

Key words: psychobiotics, COVID-19, gastrointestinal symptoms, gut microbiota, microbial dysbiosis, depression, GABA, tryptophan
\end{abstract}

Глобальная пандемия коронавирусного заболевания 2019 года (COVID-19) стала серьезной угрозой для человечества. Любой человек в условиях пандемии может стать уязвимым в зависимости от воздействия социальных факторов: самоизоляции, внезапной потери дохода или доступа к социальной поддержке, гиподинамии и т. д. В группе риска не только пожилые люди, лица с сопутствующими заболеваниями, бездомные, но и те, которые не могут справиться с финансовым, психическим или физическим кризисом. Таким образом, становится актуальной проблема оценки психологических, социальных и других последствий COVID-19 и поиск возможностей диминуации его стрессогенных нарушений [8].

Желудочно-кишечные симптомы, такие как диарея, тошнота и рвота, являются общими симптомами коронавирусной болезни и затрагивают до $28 \%$ пациентов $[10,14]$. Клинические исследования пациентов с COVID-19 показали, что желудочно-кишечные расстройства предшествуют респираторным симптомам или следуют за ними. Некоторыми авторами была изучена микробиота кишечника во время респираторных вирусных инфекций, и выдвинуто предположение, что борьба с дисбактериозом кишечника может помочь контролировать патогенез COVID-19 [13]. Современные исследования подтверждают значимую роль микробиома кишечника в регуляции психических функций, в частности настроения и поведения. Микрофлора кишечника является ключевым фактором, опосредующим взаимосвязь между особенностями питания и депрессивными расстройствами. Как легкодоступное и эффективное средство для изменения микробного состава, нормализация рациона питания может стать приемлемой альтернативой лекарственной терапии с неприятными побочными эффектами, особенно у пациентов с мягкими симптомами депрессии. Это имеет большое значение для профилактики и лечения таких распространенных психических расстройств, как депрессивные состояния $[1,2]$. В научной литературе описаны исследования многомерных связей между фактором микробиоты человека, воздействием стрессоров и связанными с этим нарушениями психического здоровья, включая стрессиндуцированные психические расстройства, представлены данные о соотнесенности микробиоты, с одной стороны, и патогенеза и симптоматики аффективных (тревожных, депрессивных и тревожно-депрессивных) расстройств. Микробиота может влиять на процесс возникновения и протекания психических феноменов различного типа и уровня выраженности, как в норме, так и при различного рода патологиях [4].

В целом функции микробиома могут иметь значительные индивидуальные вариации, однако различные его композиции у разных индивидов могут иметь сходный набор. Влияние пробиотиков и различных вариантов 
питания на микробиом кишечника подтверждают тот факт, что диета может быть возможной мишенью для микробной модификации и, в свою очередь, ослабления симптомов психического заболевания. Исследование эффективности пре- и пробиотиков предполагает перспективы в лечении психических расстройств, так как положительные изменения в диете в целом, несомненно, необходимы для долгосрочного улучшения состояния здоровья [1].

Гамма-аминомасляная кислота (ГАМК) является активным биогенным веществом, а ее продуцентами среди бактерий являются молочнокислые представители. Известно, что ГАМК обладает антигипертензивным, анальгетическим и антидепрессантным свойствами. Лактобациллы - продуценты ГАМК рассматриваются в качестве вектора ее доставки в нужное место в кишечнике и могут быть использованы как средство, способствующее адаптации человека к условиям среды. Рядом ученых была изучена способность лактобацилл и бифидобактерий, явлющимися компонентами микробиоценоза ЖКТ человека, синтезировать ГАМК. Оказалось, что из 114 штаммов лактобацилл и бифидобактерий способностью синтезировать ГАМК обладают все представители видов L.plantarum, L.brevis, B.adolescentis, B.angulatum, B.dentium (58 штаммов). Наибольшее количество ГАМК продуцировали штаммы бифидобактерий (до 6 г/л). Отобран один ГАМК-продуцирующий штамм L.plantarum 90sk, и показано, что его прием крысами линии Спрэг-Доули приводит к повышению в крови уровня этой аминокислоты и к снижению уровня гормона стресса - пролактина. Авторы предложили использование штамма L.plantarum 90sk в качестве потенциального психобиотика, способного улучшить адаптацию человека к условиям среды [5].

В этиологии и патогенезе депрессии существенную роль играют нарушения нейромедиаторного обмена. В частности, дефицит моноаминов (норадреналина, серотонина) способен приводить к нарушению синаптической передачи в нейронах лимбической системы и формировать депрессивные расстройства. Серотонин (5-НТ, 5гидрокситриптамин) образуется из триптофана, получаемого с пищей. После выделения в синаптическую щель серотонин подвергается обратному захвату, а затем окислительному дезаминированию. Наибольшую патогенетическую значимость в коррекции эмоциональных нарушений и развитии антидепрессивного эффекта имеет связывание свободного серотонина с рецепторами 5-НТ . В экспериментах по трансплантации несбалансированной кишечной микробиоты мыши, страдающей умеренным хроническим стрессом, здоровым мышам-реципиентам было выявлено депрессивное поведение с уменьшением нейрогенеза в гиппокампе и снижением уровня серотонина (в последнем случае отмечалось ограничение его синтеза и обратного захвата, а также стимуляция распада). По-видимому, в этом процессе участвует триптофан, метаболизм которого может изменяться при дисбиозе что можно объяснить уменьшением бактериального кластера в связи с более низкими уровнями триптофана. Таким образом, наступление дисбиоза кишечника может объяснить наличие определенных форм депрессии из-за изменения серотонинергического пути метаболизма триптофана. По мнению авторов, воздействие на микроорганизмы, участвующие в катаболизме триптофана, представляет собой потенциальную стратегию терапии [12]. В то же время уровень триптофана в плазме крови может служить биомаркером в процессе выбора оптимальной терапии в стрессогенных условиях пандемии.

Было высказано предположение, что определенные микроорганизмы имеют возможность оказывать влияние (положительное или отрицательное) на пищевые привычки хозяина и его эмоциональное поведение посредством секреции различных нейроактивных молекул и прочих гормоноподобных веществ. С другой стороны, бактерии имеют рецепторы этих гормонов, поэтому они могут связываться с мозгом хозяина. Например, как уже было указано выше, лактобациллы и бифидобактерии способны синтезировать нейромедиаторную ГАМК, которая уменьшает беспокойство и стресс, в то время как Escherichia, Bacillus и Saccharomyces производят норадреналин [6]. Хронический стресс, в принципе, сопровождается повышением выделения медиаторов воспаления и риском развития инфекции, появлением воспалительных заболеваний, а также депрессивных расстройств. Нарушение нормального состава микрофлоры кишечника ассоциируется с повышенной реакцией гипоталамо-гипофизарнонадпочечниковой системы, повышением уровня провоспалительных цитокинов, снижением стрессоустойчивости и депрессией [3]. Изучение процессов, происходящих на микробиом-кишечно-мозговой оси, открывает перспективы применения нового метода в комплексной терапии депрессивных и тревожных расстройств, имеющего патогенетическую направленность. В научной литературе, в контексте изучения влияния микробиоты на развитие и течение тревожных и депрессивных расстройств, приведены результаты первых клинических испытаний лекарственных средств, получивших название «психобиотки», а также выделены основные патогенетические механизмы депрессии и тревоги, являющиеся мишенью для анксиолитического и антидепрессивного действия психобиотиков [2].

Некоторые авторы предлагают гастроэнтерологам учитывать желудочно-кишечные симптомы при скрининге и обнаружении COVID-19 на момент постановки дифференцированного диагноза. При раннем и появлении de novo диареи, тошноты или рвоты, при отсутствии выявления другой этиологии этих симптомов, ожидается обследование пациента на инфекцию SARS-CoV-2. В противном случае существует риск поздней диагностики COVID-19. Риск развития желудочно-кишечных симптомов и изменений биомаркеров печени увеличивается у пациентов с тяжелой формой COVID-19, что ухудшает прогноз и увеличивает продолжительность заболевания. При его умеренном течении, желудочно-кишечные и печеночные симптомы 
возникают реже и часто носят преходящий характер, соответственно, не требуют патогенетического лечения. Декомпенсированный цирроз печени, гепатоцеллюлярная карцинома, тяжелые формы воспалительного заболевания кишечника следует рассматривать как факторы риска развития тяжелых форм COVID-19, с неблагоприятным прогнозом. Вирус в фекалиях может сохраняться до 5 недель после получения отрицательного результата мазка из носоглотки, но это не подтверждает существования фекально-орального пути заражения, поскольку стабильность вируса и его жизнеспособности в фекалиях еще не достаточно изучены [12].

Итальянские исследователи показали, что повышенный уровень кальпротектина у пациентов с COVID-19 свидетельствует о том, что коронавирус вызывает воспалительный ответ в кишечнике. У здорового человека кальпротектин выполняет регулирующую функцию в воспалительном процессе и обладает как антимикробным, так и антипролиферативным свойствами. Он высвобождается в просвет кишечника во время активации лейкоцитов или в результате их деградации. Диагностическая ценность фекального кальпротектина при широком спектре кишечных расстройств изучалась несколькими группами исследователей, которые доказали его корреляцию с активностью заболевания у пациентов с воспалительным заболеванием кишечника [7, 11].

Предыдущие исследования показали, что SARS-CoV-2 связывается с клетками желудочно-кишечного тракта (например, эпителиальными клетками тонкого и толстого кишечника), вероятно, через специфические рецепторы, такие как ACE2 и трансмембранную сериновую протеазу [9]. Считается, что этот вирус заражает эпителиальные клетки, вызывая высвобождение цитокинов и хемокинов, провоцируя острое воспаление кишечника, характеризующееся инфильтрацией нейтрофилов, макрофагов и Т-клеток. Имеются доказательства того, что инфекция SARS-CoV-2 у пациентов с COVID-19 провоцирует воспалительный ответ в кишечнике, о чем свидетельствует диарея и увеличение IL-6 [11]. Фекальная PHK SARS-CoV-2 не обнаруживалась во время острой диареи, но была обнаружена у бессимптомных пациентов с предыдущими диарейными симптомами или без них. В настоящее время неизвестно, влияет ли инфекция SARS-CoV-2 на пациентов с воспалительными заболеваниями кишечника и влияет ли иммуносупрессивная терапия на их восприимчивость к COVID-19. Действия по изменению состава кишечной микробиоты в сторону превалирования штаммов из родов Bifidobacterium и Lactobacillus приведут к повышению барьерной функции кишечника и укреплению иммунитета. В настоящее время в условиях пандемии особо важно рассматривать «психобиотики» в качестве способа целенаправленного воздействия на организм человека, способствующим улучшению течения коронавирусной инфекции или постковидных состояний. В рамках стратегии изучения микробиоты, с одной стороны необходимо идентифицировать представителей, которые достаточно выраженно влияют на развитие психических и психосоматических расстройств, а с другой стороны - получить подтверждение/опровержение гипотезы о том, что действие микробиоты на ЦНС связано с ее метаболической активностью, на который оказывают влияние факторы окружающей среды, в частности диета, стресс или воспаление [4].

\section{Выводы:}

1. Двусторонняя связь между кишечником и мозгом, которая оказывает большое влияние на общее состояние здоровья, особенно чувствительна в стрессогенных условиях пандемии, при которых страдает микрофлора психобиотического действия, что ассоциируется со снижением стрессоустойчивости и депрессией.

2. Нормальная микрофлора ЖКТ особо уязвима в условиях пандемии под влиянием стресс-факторов среды, а также под влиянием медикаментозной терапии COVID-19, особенно в случае тяжелого течения заболевания.

3. Уровень триптофана в плазме крови может служить биомаркером в процессе выбора оптимальной терапии психических нарушений в условиях пандемии.

4. Введение в рацион питания препаратов, содержащих психобиотики, а также некоторые аминокислоты позволит положительно влиять как на регуляцию психических функций, так и на бактериоценоз кишечника в условиях пандемии и/или постпандемии COVID-19.

\section{Список литературы:}

1. Барыльник Ю.Б., Шульдяков А.А., Филиппова Н.В., Рамазанова К.Х. Микробиом кишечника человека и психическое здоровье: состояние проблемы. Российский психиатрический журнал. № 3, 2015 , с. 30-41.

2. Кирпиченко А.А., Ким И.Ю. Психобиотики: способна ли микробиота кишечника оказывать влияние на психическое здоровье хозяина? Витебский государственный ордена Дружбы народов медицинский университет. Вестник ВГМУ. 2017, т. 16, №2, с. 26-42.

3. Комарова О.Н., Хавкин А.И. Взаимосвязь стресса, иммунитета и кишечной микробиоты. Педиатрическая фармакология. 2020; 17 (1): 18-24.

4. Михайлова А.П., Ченченко Д.В, Штрахова А.В. Микробиотический фактор, здоровье и стрессиндуцированные психические расстройства. Вестник ЮУрГУ. Серия «Психология». 2018. т. 11, № 1, с. 75-87.

5. Юнес Р.А., Полуэктова Е.У., Дьячкова М.С., Козловский Ю.Е., Орлова В.С., Даниленко В.Н.. Отбор бактерий-симбионтов рода Lactobacillus и Bifidobacterium по их способности синтезировать гаммааминомасляную кислоту - один из подходов в получении психобиотиков. Вестник РУдН, серия Экология и безопасность жизнедеятельности, 2016, № 4, с.51-59. 
6. Dehhaghi, M., Kazemi Shariat PHAahi, H., Guillemin, G.J. Microorganisms' Footprint in Neurodegenerative Diseases. Front. Cell Neurosci. 2018, 12, 466.

7. Effenberger M., Grabherr F., Mayr L., et al. Faecal calprotectin indicates intestinal inflammation in COVID-19. Gut. 2020; 69:1543-1544.

8. Emily A Holmes, Rory C O’Connor, V Hugh Perry et al. Multidisciplinary research priorities for the COVID-19 pandemic: a call for action for mental health science. Lancet Psychiatry . 2020. - Vol. 7, p. 547-560.

9. Hoffmann M, Kleine-Weber H, Schroeder S, et al. SARS-CoV-2 cell entry depends on ACE2 and TMPRSS2 and is blocked by a clinically proven protease inhibitor. Cell. 2020. 10.1016/j.cell.2020.02.052.

10. Lin L, Jiang X, Zhang Z, et al. Gastrointestinal symptoms of 95 cases with SARS-CoV-2 infection. Gut 2020. 10.1136/gutjnl-2020-321013.1-5.

11. Magro F, Lopes J, Borralho P, et al. Comparison of different histological indexes in the assessment of UC activity and their accuracy regarding endoscopic outcomes and faecal calprotectin levels. Gut. 2019; 68:594-603.

12. Siopi E, Chevalier G, Katsimpardi L, et al. Changes in Gut Microbiota by Chronic Stress Impair the Efficacy of Fluoxetine. Cell Rep. 2020, Mar 17; 30(11):3682-3690.

13. Trottein F, Sokol H. Potential Causes and Consequences of Gastrointestinal Disorders during a SARS-CoV-2 Infection. Cell Rep. 2020 Jul 21;32(3):107915.

14. Xiao F, Tang M, Zheng X, et al. Evidence for gastrointestinal infection of SARS-CoV-2. Gastroenterology. 2020. 10.1053/j.gastro.2020.02.055. 